\title{
PREDICTION OF ECOLOGICAL IMPORTANCE OF CARABIDAE BIOTOPES USING COMMUNITY INDEX OF THE GROUND BEETLES (IKS) IN THE SOUTHERN PART OF CENTRAL SLOVAKIA
}

\author{
LANGRAF, V..$^{*}$ - PETROVIČOVÁ, K. ${ }^{2}$ - DAVID, S. ${ }^{3}$ - SvORAdOVÁ, A. ${ }^{4}-$ SCHLARMANNOVÁ, J. ${ }^{5}$ \\ ${ }^{1}$ L'udovita Okánika 14, 94901 Nitra, Slovak Republic \\ ${ }^{2}$ Department of Environment and Zoology, Faculty of Agrobiology and Food Resources Slovak \\ University of Agriculture in Nitra, Tr. A. Hlinku 2, 94976 Nitra, Slovak Republic \\ ${ }^{3}$ Department of Ecology and Environmental Sciences, Faculty of Natural Sciences, Constantine \\ the Philosopher University in Nitra, Tr. A. Hlinku 1, Nitra, Slovak Republic \\ ${ }^{4}$ Research Institute for Animal Production in Nitra, National Agricultural and Food Centre \\ Hlohovecká 2, 95141 Lužianky, Slovak Republic \\ ${ }^{5}$ Department of Zoology and Anthropology, Faculty of Natural Sciences, Constantine the \\ Philosopher University in Nitra, Tr. A. Hlinku 1, Nitra, Slovak Republic \\ *Corresponding author \\ e-mail: langrafvladimir@gmail.com \\ (Received $13^{\text {th }}$ Aug 2019; accepted $25^{\text {th }}$ Nov 2019)
}

\begin{abstract}
Using the community index of the ground beetles (IKS) the quality status of 4 habitat types in 6 localities of, Stolické vrchy and Juhoslovenská kotlina basin (The Southern Part Of Central Slovakia) were evaluated. In the 2015-2017 period we noticed 2,379 individuals (1,030 ${ }^{\lambda}, 1,349$ + ) belonging to 52 species. Friedman's test showed a significant difference in IKS values in years 2015-2017 between study areas. By calculating IKS we found a greater number of adaptable species in areas with lower habitat disturbance (quality class III) compared to higher disturbance (quality class I), where eurytopic species predominated. We predicted an increase in IKS values for 2020 and 2022 for the habitats including meadow (area 1), nitrophilous waterside vegetation (areas 2,6) and a decrease for pasture habitat (area 3), nitrophilous waterside vegetation (area 4) and fallow field (area 5) using the regression polynomial and exponential distribution models.
\end{abstract}

Keywords: Carabidae, Stolické vrchy, Juhoslovenská kotlina, assessment of habitats quality, bioindication classes $(A, E, R)$

\section{Introduction}

For the bioindication and monitoring changes in the quality of the environment, the Carabidae family (Coleoptera) is the most commonly used (Nietupski et al., 2015; Burgio et al., 2015). Carabidae inhabit different habitat types, especially meadow, field and forest habitats (Heydeman, 1955; Hůrka, 1996). Most species have a narrow ecological valence and therefore respond sensitively to changes in habitat conditions ( $\mathrm{pH}$, soil moisture changes) as well as the presence of toxic substances including herbicides and insecticides. Changes in the species structure of the short-lived communities reflect various long-term environmental changes. Bioindicative use is based on assessing the impact of human economic activities (Cardamo and Spence, 1994; Porhajašová et al., 2008, 2009). 
We have already conducted similar faunistic research, the results of which can be found in the following references: Langraf et al., 2016b, 2018a. We processed data of 54 species ( $\mathrm{N}=4,675$ individuals) serving as an input dataset for the calculation of indexes for ellipsoid biovolume (EV), flight ability and community index of the ground beetles (IKS). Pilot results (Langraf et al., 2016a) confirm a negative anthropogenic impact on the forest ecosystem, which means the worsening of living conditions for adaptable and relict species. We found out the prevalence of eurytopic species (IKS bioindication group E) in intensively influenced forest and meadow habitats of the Juhoslovenská kotlina basin. Langraf et al. (2017, 2018b) assessed the elipsoid biovolume (EV) and flight ability indices on 5 habitat types (forest, fallow field, meadow, pasture, nitrophilic waterside vegetation). The results confirm a decrease in EV index values and an increase in the number of flight ability (eurytopic) species on habitats with higher anthropogenic disturbance. On the contrary, with decreasing anthropic intervention, the value of the EV index and thus the number of apteric and brachypterous species increases. In the last study (Langraf et al., 2019) we evaluated all 3 bioindication methods in forest ecosystems. We confirmed the correlation of the decrease of IKS, EV index values and increase of eurytopic species due to anthropogenic disturbance of forest ecosystems by cutting.

Monitoring of gradual successive changes and the impact of management on agricultural land is also important for bioindicative evaluation. Compared to natural ecosystems, biodiversity is reduced in agricultural areas. Typical Carabidae bound to arable land reported Vician et al. $(2010,2011)$ as follows: Amara aenea, Anchomenus dorsalis, Calathus fuscipes, Clivina fossor, Harpalus affinis, $H$. distinguendus and Pseudoophonus rufipes. Št'astná and Bezděk (2004), Purchart and Kula (2005), Baranová et al. (2013), Lemic et al. (2017) recorded the predominance of eurytopic species over adaptable (terminology used in IKS assessment) in the agricultural areas of the family Carabidae as a consequence of habitat disturbance. The species represented by a high number of individuals were: Anchomenus dorsalis, Poecilus cupreus, Pseudoophonus rufipes and Pterostichus melanarius. Igondová and Majzlan (2015) confirmed the lowest IKS values at the field-meadow edge and the meadow playground. The highest IKS values were recorded in forest areas and peatbogs. The prevalence of eurytopic species over adaptable to Permanent grassland has been reported by Jad'ud'ová et al. (2016). Stluka (2013) investigated the Carabidae on three habitats: spruce forest, spruce nursery and glade.

The IKS index in the glade found a strong anthropogenic impact with a predominance of group E (see chapter Methodology) and the lowest in the spruce forest with a predominance of group A species. It is clear that the intensity of management influences the biodiversity of the forest ecosystem. Rajová (2007) found in 10 localities of Klánovice forest in 2000 and 2001 a higher proportion of adaptable species compared to eurytopic, but significant decrease of stenotopic (relict) species. This fact points to anthropogenic influence of forest and worsening of living conditions of stenotope (relict) species. The lowest value of IKS was recorded by the author at 2 marginal forest localities the remaining forest areas had higher IKS values.

The destruction of the microorganism environment due to forest cutting leads to the loss of specific forest species of Carabidae and their replacement by eurytopic species, which are typically found in open habitats, ruderal habitats and fields (Elek et al., 2001; Finch, 2005; Wiezik et al., 2007). According to Niemelä et al. (2002), urbanization 
causes a decrease in the biodiversity of Carabidae species and in most cases increases the number of small species belonging to bioindication group $\mathrm{E}$ towards the city center.

In this study we continue with the bioindicative evaluation of the Carabidae obtained during the years 2015-2017 in Stolické vrchy and Juhoslovenská kotlina basin for prediction models.

The aim of the paper is to set habitat quality using IKS on 6 study areas representing 4 habitat types with different intensity of anthropogenic activity (habitat management). We evaluated the working hypotheses: (1) IKS value decreases in the direction from anthropically less disturbed habitats to anthropically more disturbed; (2) in unstable habitats disturbed by anthropic activity, there is a predominance of species from bioindication group E; (3) in more stable habitats less disturbed by anthropic activity, the predominance of species from bioindication group A is predominant.

\section{Material and methods}

Ground beetles were collected from April to October 2015-2017 in 6 localities (Fig. 1) representing 4 types of biotopes, classified according to Ružičková et al. (1996). The following crops were grown in the contact area of sites 4, 5 and 6: wheat, barley, sunflower, maize and rape. We used pitfall traps $(750 \mathrm{ml})$, yellow pan trap $(1,500 \mathrm{ml})$ (Novák et al., 1969) which were arranged at each biotope in a trap line, and each trap line consisted of five pitfall traps (at $10 \mathrm{~m}$ intervals). The material was collected in eat regular three-week intervals. As a killing agent, 4\% saline solution was used.

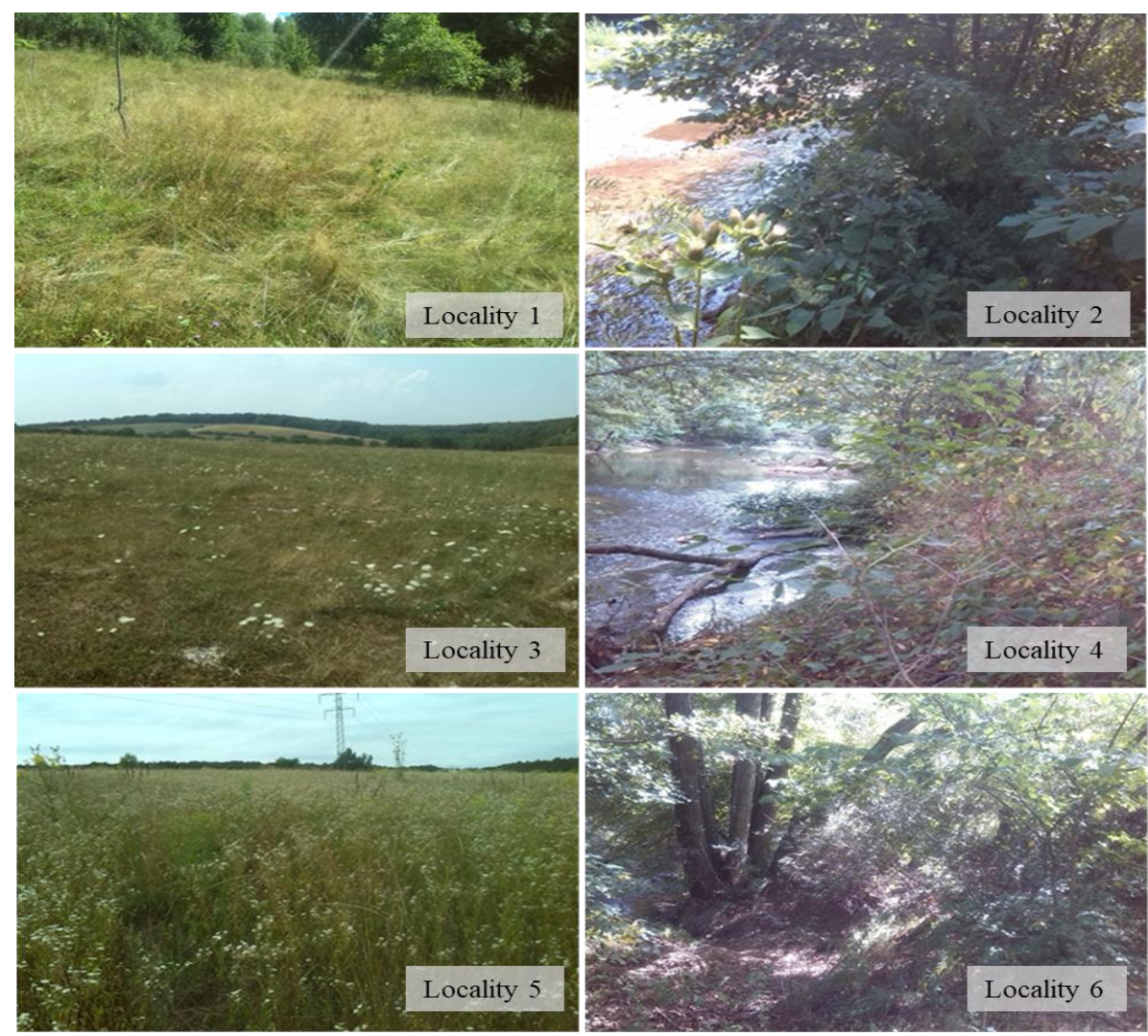

Figure 1. Study localities (1 - 6) (photos: Langraf, 2015) 


\section{Study area}

The study localities are located in the geomorphological units Stolické vrchy and Juhoslovenská kotlina basin (The Southern Part Of Central Slovakia) (Fig. 2). Location data and habitat characteristics of the areas are shown in Table 1.
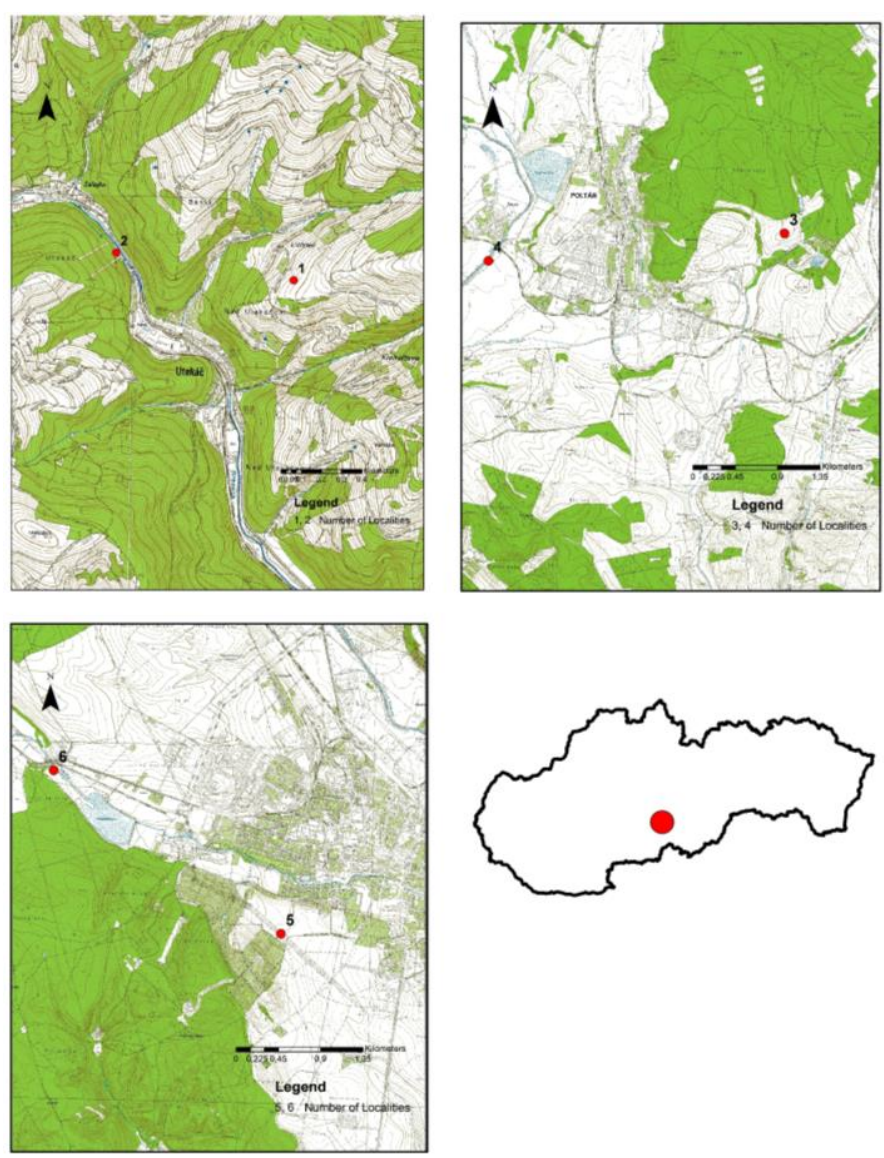

Figure 2. A map indicating the location of sampling sites

Table 1. Location data of the study localities

\begin{tabular}{|c|c|c|c|c|c|}
\hline Geomorphological unit & Study area & C. a. & $\begin{array}{c}\mathbf{m} \\
\text { a.s.l. }\end{array}$ & biotope & G.C. \\
\hline \multirow{2}{*}{ Stolické vrchy } & 1 Lichovo & Utekáč & 556 & meadow & $\begin{array}{l}48^{\circ} 36^{\prime} 30^{\prime \prime} \mathrm{S} \\
19^{\circ} 48^{\prime} 35^{\prime \prime} \mathrm{V}\end{array}$ \\
\hline & 2 Farkaška & Utekáč & 446 & $\begin{array}{c}\text { nitrophilous waterside } \\
\text { vegetation }\end{array}$ & $\begin{array}{l}48^{\circ} 36^{\prime} 34^{\prime \prime} \mathrm{S} \\
19^{\circ} 47^{\prime} 52^{\prime \prime} \mathrm{V}\end{array}$ \\
\hline \multirow{4}{*}{$\begin{array}{l}\text { Juhoslovenská kotlina } \\
\text { basin }\end{array}$} & 3 Prievranka & Poltár & 272 & pasture & $\begin{array}{l}48^{\circ} 25^{\prime} 52^{\prime \prime} \mathrm{S} \\
19^{\circ} 49^{\prime} 08^{\prime \prime} \mathrm{V}\end{array}$ \\
\hline & 4 Pažit' & Poltár & 218 & $\begin{array}{c}\text { nitrophilous waterside } \\
\text { vegetation }\end{array}$ & $\begin{array}{l}48^{\circ} 25^{\prime} 41^{\prime \prime} \mathrm{S} \\
19^{\circ} 46^{\prime} 35^{\prime \prime} \mathrm{V}\end{array}$ \\
\hline & $\begin{array}{l}5 \text { Zajačie } \\
\text { brehy }\end{array}$ & \begin{tabular}{|c|} 
Lučene \\
$\mathrm{c}$
\end{tabular} & 208 & fallow field & $\begin{array}{c}48^{\circ} 19^{\prime} 017^{\prime \prime} \mathrm{S} \\
19^{\circ} 39^{\prime} 05^{\prime \prime} \mathrm{V}\end{array}$ \\
\hline & 6 L'adovo & $\begin{array}{c}\text { Lučene } \\
\mathrm{c}\end{array}$ & 207 & $\begin{array}{c}\text { nitrophilous waterside } \\
\text { vegetation }\end{array}$ & $\begin{array}{l}48^{\circ} 20^{\prime} 12^{\prime \prime} \mathrm{S} \\
19^{\circ} 37^{\prime} 06^{\prime \prime} \mathrm{V}\end{array}$ \\
\hline
\end{tabular}

C. a. - Cadastral area; $m$ a.s.l. - metres above sea level; G.C. - geographic coordinates 


\section{Computation community index of the ground beetles (IKS)}

Ground beetles we divided into three bioindication classes according to Farkač et al. (2006):

Group $\mathrm{R}$ - relicts, stenotopic species, narrow ecological valence - mostly rare and endangered species of natural ecosystems.

Group A - adaptable species which colonize semi-natural habitats, they occur in secondary, good regenerating biotopes and its ecotones.

Group E- eurytopic species without special requirements on the character and quality of environment. They occur in unstable and changing biotopes with strong anthropogenic influence.

The Index of Community of ground beetles (IKS) is calculated according to Nenadál (1998) based on the division of the Carabidae into bioindication groups (A, E, R). We use the following formula:

$$
\mathrm{IKS}=100-(\Sigma \mathrm{E}+0.5 \times \Sigma \mathrm{A})
$$

where $\mathrm{E}=$ percentage of individuals in group $\mathrm{E}(\mathrm{E} \%), \mathrm{A}=$ percentage of individuals in group $\mathrm{A}(\%)$.

The IKS index includes the values ranging from zero to 100. In cases where the index value is close to zero, we identified mostly species of group E. Conversely, when the value of index is close to 100; there are mostly species from group $\mathrm{R}$. The final values included five classes according to the Nenadal's (1998) classification scale of human influence on habitat: I (0-15) strongly influenced, II (10-35) significantly influenced, III (30-50) influenced, IV (45-65) marginally influenced and V (65-100) not influenced.

\section{Data analyses}

Statistical analysis of IKS data on the study areas in years 2015-2017 using the programs Statistica Cz. Ver. 7.0 (StatSoft, 2004; Ter Brak and Šmilauer, 2002), CanoDraw 4.5 (Ter Brak and Šmilauer, 2002) and the Excel 2016 Analysis Program (Barrila et al., 2016) were evaluated.

For data assessment Detrended Correspondence Analysis (DCA), Redundancy Analysis (RDA), normality distribution (Shapiro-Willksov W test), testing of variance from mean values Friedman test (ANOVA), testing of selected correlation relations (polynomial regression, exponential distribution) were used. Statistical significance of the environment (luminance, humidity and $\mathrm{pH}$ ) was tested by the Monte Carlo permutation test.

\section{Results}

In the study area of Stolické vrchy and Juhoslovenská kotlina basin using both methods (pitfall traps, yellow pan trap) we recorded 2,379 individuals $(1,030 \lambda$, 1,349 ㅇ) belonging to 52 species. Based on the division of the Carabidae into bioindication groups (A, E, R) to tolerate anthropogenic effects, we calculated the Carabidae IKS for each area examined. We recorded the highest species distribution in the localities in group A (31 species; 66.62\%). To a lesser extent, group E species (18 species; $32.45 \%)$ were represented. Group R was represented by 3 species $(0.92 \%)$ (Table 2). 
Table 2. Distribution of the Carabids based on bioindication groups in the study areas

\begin{tabular}{|c|c|c|c|c|c|c|c|}
\hline \multirow{2}{*}{ Species } & \multirow{2}{*}{ IKS } & \multicolumn{6}{|c|}{ Study areas } \\
\hline & & 1 & 2 & 3 & 4 & 5 & 6 \\
\hline Abax ovalis (Duftschmid, 1812) & A & 1 & 1 & - & - & - & 1 \\
\hline Abax parallelepipedus (Pill. \& Mitt.,1783) & A & 15 & 28 & 1 & 44 & 1 & 139 \\
\hline Abax parallelus (Duftschmid, 1812) & A & 20 & 43 & - & 3 & - & 73 \\
\hline Agonum viduum (Panzer, 1797) & A & - & - & - & - & - & 1 \\
\hline Amara aenea (DeGeer, 1774) & A & 1 & - & 2 & - & 2 & - \\
\hline Amara aulica (Panzer, 1797) & A & - & 2 & - & - & - & - \\
\hline Amara erratica (Duftschmid, 1812) & $\mathrm{R}$ & 8 & - & - & - & - & - \\
\hline Amara familiaris (Duftschmid, 1812) & $\mathrm{E}$ & - & - & 6 & - & - & 1 \\
\hline Amara saphyrea (Dejean, 1828) & A & - & - & - & - & - & 2 \\
\hline Amara similata (Gyllenhal, 1810) & $\mathrm{E}$ & - & - & 1 & - & - & 1 \\
\hline Anchomenus dorsalis (Pontopp, 1763) & E & - & - & 3 & 1 & 2 & 10 \\
\hline Brachinus crepitans (Linnaeus, 1758) & E & - & - & 6 & 1 & 2 & - \\
\hline Brachinus explodens (Duftschmid, 1812) & $\mathrm{E}$ & - & - & - & 1 & - & - \\
\hline Calathus fuscipes (Goeze, 1777) & E & 7 & - & 12 & - & - & - \\
\hline Calathus melanocephalus (Linnaeus, 1758) & $\mathrm{E}$ & - & - & 2 & - & - & - \\
\hline Callistus lunatus (Fabricius, 1775) & A & - & - & - & - & 3 & - \\
\hline Carabus cancellatus (Illiger, 1798) & A & 28 & 36 & - & - & - & - \\
\hline Carabus convexus (Fabricius, 1775) & A & 4 & 9 & - & - & - & - \\
\hline Carabus coriaceus (Linnaeus, 1758) & A & - & 3 & 5 & 11 & 2 & 9 \\
\hline Carabus glabratus (Paykull, 1790) & A & 6 & 10 & - & - & 1 & - \\
\hline Carabus granulatus (Linnaeus, 1758) & $\mathrm{E}$ & 1 & 29 & - & - & - & 9 \\
\hline Carabus hortensis (Linnaeus, 1758) & A & 2 & 20 & - & - & - & 2 \\
\hline Carabus intricatus (Linnaeus, 1761) & A & - & 4 & - & - & - & 6 \\
\hline Carabus nemoralis (O.F.Müller, 1764) & A & 36 & 4 & - & - & 1 & - \\
\hline Carabus scheidleri (Panzer, 1799) & A & 2 & - & 3 & 5 & 255 & 1 \\
\hline Carabus ullrichi (Germar, 1824) & A & - & 39 & - & - & 46 & - \\
\hline Carabus violaceus (Linnaeus, 1758) & A & 81 & 4 & 12 & - & 98 & 16 \\
\hline Cicindela germanica (Linnaeus, 1758) & A & - & - & 9 & - & 17 & - \\
\hline Cychrus caraboides (Linnaeus, 1758) & A & - & 1 & - & - & - & - \\
\hline Cymindis humeralis (Fourcroy, 1785) & A & - & - & - & - & 1 & 2 \\
\hline Drypta dentata (Rossi, 1790) & $\mathrm{E}$ & - & - & 3 & - & 3 & - \\
\hline Elaphrus aureus (P. Müller, 1821) & $\mathrm{R}$ & - & - & - & 3 & - & 5 \\
\hline Harpalus affinis (Schrank, 1781) & $\mathrm{E}$ & 6 & - & 350 & - & 4 & - \\
\hline Harpalus froelichi (Sturm, 1818) & A & - & - & - & 7 & - & - \\
\hline Harpalus rubripes (Duftschmid, 1812) & E & 39 & - & 5 & 3 & 1 & - \\
\hline Lebia chlorocephala (Hoffm. a kol., 1803) & A & 2 & - & 1 & - & - & - \\
\hline Leistus rufomarginatus (Duftschmid, 1812) & $\mathrm{R}$ & - & - & - & - & - & 6 \\
\hline Molops piceus (Fabricius, 1801) & A & 9 & 3 & - & - & - & - \\
\hline Nebria brevicollis (Fabricius, 1792) & A & 6 & 9 & - & 17 & 1 & 94 \\
\hline Notiophilus biguttatus (Fabricius, 1799) & A & - & - & - & 1 & - & - \\
\hline Ophonus azureus (Fabricius, 1775) & $\mathrm{E}$ & - & - & - & - & 3 & - \\
\hline Ophonus nitidulus (Stephens, 1828) & A & - & 2 & - & - & - & - \\
\hline Platynus assimilis (Paykull, 1790) & A & - & 16 & - & 74 & - & 109 \\
\hline Poecilus cupreus (Linnaeus, 1758) & $\mathrm{E}$ & 13 & 1 & 36 & - & 34 & - \\
\hline Poecilus versicolor (Sturm, 1824) & $\mathrm{E}$ & - & - & 2 & - & - & - \\
\hline Pseudoophonus rufipes (DeGeer, 1774) & $\mathrm{E}$ & 11 & - & 58 & 34 & 28 & 4 \\
\hline Pterostichus melanarius (Illiger, 1798) & $\mathrm{E}$ & - & 17 & - & 13 & 2 & 4 \\
\hline Pterostichus melas (Creutzer, 1799) & A & 1 & - & - & - & - & - \\
\hline Pterostichus niger (Schaller, 1783) & A & 9 & 1 & - & 11 & 3 & 5 \\
\hline Pterostichus nigrita (Paykull, 1790) & $\mathrm{E}$ & - & - & - & 2 & - & - \\
\hline Pterostichus oblongopunctatus (Fab., 1787) & A & - & 19 & - & 7 & 3 & 1 \\
\hline Zabrus tenebrioides (Goeze, 1777) & $\mathrm{E}$ & - & - & 1 & - & - & - \\
\hline S individuals & - & 308 & 301 & 518 & 238 & 513 & 501 \\
\hline$\sum$ species IKS -A & - & 16 & 20 & 7 & 10 & 14 & 15 \\
\hline$\sum$ species IKS -E & - & 6 & 3 & 13 & 7 & 9 & 6 \\
\hline $\bar{\sum}$ species IKS -R & - & 1 & - & - & 1 & - & 2 \\
\hline IKS 2015 & - & 34,21 & 42,31 & 3,795 & 40,19 & 45,77 & 46,94 \\
\hline IKS 2016 & - & 40,64 & 41,5 & 4,715 & 39,785 & 39,455 & 47,045 \\
\hline IKS 2017 & - & 41,385 & 50 & 0 & 34,21 & 42,16 & 50,275 \\
\hline Total value IKS for years 2015 - 2017 & - & 38,8 & 42,195 & 3,185 & 39,075 & 42,3 & 48,2 \\
\hline Class/quality of habitat & - & III & III & I & III & III & III \\
\hline
\end{tabular}

Class I (0-15) very influenced, Class II (10-35) heavily influenced, Class III (30-50) influenced, Class IV (45-65) not influenced, Class V (65-100) not affected 
The lowest value of IKS was observed in the area of 3 (pastures), which shows the highest anthropogenic interference in the study areas. There were 4 species preferring arable land find in the area 1: Amara aenea, Calathus fuscipes, Harpalus affinis and Pseudoophonus rufipes, which were represented by a low number of individuals. The arable land (areas 3 and 5) species were represented by a higher number of individuals Amara aenea, Anchomenus dorsalis, Calathus fuscipes, Harpalus affinis and Pseudoophonus rufipes. Indeed, the intensive agricultural use of the landscape prevails around areas 3 and 5. Fallow field of the watercourses of the locality had different IKS values. The lowest value was recorded in area 4, where 2 species Anchomenus dorsalis and Pseudoophonus rufipes favoring arable land. Areas 2 and 6 were connected with forest fields, therefore adaptable species predominated and IKS values were higher than in area 4.

We evaluated the difference in representation of bioindication groups $\mathrm{A}, \mathrm{E}, \mathrm{R}$ and IKS values between areas from 2015 to 2017 by RDA analysis (the highest value of lengths of gradient $=2.51$ ). The RDA analysis has values of explained variability of species data of the first ordination axis $(45.3 \%)$ and the second ordination axis $(68.4 \%)$. The variability of the species set explained by environmental variables represent by the ordinal axis is $46.3 \%$, while the second axis represents $70.5 \%$ (Fig. 3).

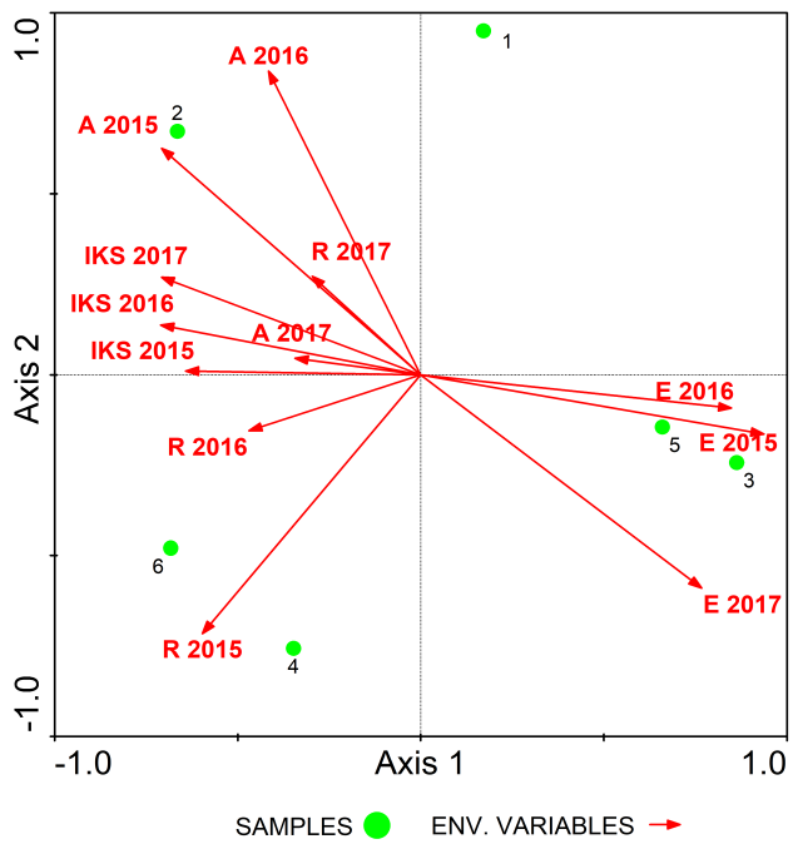

Figure 3. Representation of groups A, E, R and IKS values 2015 - 2017. Explanatory notes: A Group A, E - Group E, R - Group R, IKS - Carabidae Community Index

Ordination graph showed correlation between the group A species with the nitrophilous waterside vegetation (area 2) with their highest representation. Vectors showing individual years (2015-2017) for this group did not differ significantly, suggesting only small variations in the number of species for group A. Open spaced areas 3 and 5 were abundantly represented by group E species, as illustrated by the correlation of this group over the years 2015-2017. Vectors did not differ significantly between 2015-2016, until 2017 indicating a change in the number of group E species. 
The following fact indicates an intensification of agricultural land use. Area 1 (meadow) is ordained away from the vectors, indicating a slight variation in the proportion of bioindication groups and IKS values. Group R species correlated in 2015 with areas 4 and 6 (nitrophilic herbaceous vegetation) where they were recorded. In 2016 and 2017 there was a significant delay in vectors, which was influenced by the occurrence of $R$ group species also in area 1 . The vectors for IKS values did not significantly diverge in years 2015-2017. The following fact shows that there have been minor changes in IKS values over the years 2015-2017. The correlation with forest areas 2 and 6 was influenced by high IKS values during all 3 years.

For normality distribution in years 2015-2017 for all areas the Shapiro-Wilks W-test was used. We tested the hypothesis $\mathrm{H}_{0}$ : random selection comes from a set with normal distribution, if $\mathrm{p}>\mathrm{p} \alpha=>$ we do not reject $\mathrm{H}_{0}$ at the level of selected statistical significance $p \alpha=0.05$. As a result, the normal distribution of IKS data across all areas in 2015-2017 was disrupted ( $\mathrm{p}$-value $=0.00$ ).

A non-parametric Friedman test for testing $\mathrm{H}_{0}$ hypothesis was used because of distribution normality data disruption, which verified the $\mathrm{H}_{0}$ hypothesis: IKS values do not differ in areas in 2015-2017. This means if $\mathrm{p}>\mathrm{p} \alpha=>$ do not reject $\mathrm{H}_{0}$ at the level of statistical significance chosen by us $\mathrm{p} \alpha=0.05$. The result of the testing is the rejection of the $\mathrm{H}_{0}$ hypothesis $(\mathrm{p}=0.00)$, which means that IKS values are significantly different in all areas in 2015-2017 (Fig. 4). The gradual increase in the IKS value caused by the succession and non-mowed meadow was recorded. The same increase in IKS was also observed in area 6 , where waterside vegetation was not treated for 3 years and naturally overgrown with trees. Species of group R were found in the study areas, their presence indicates a low anthropic interference in the environment. In 2016, the waterside vegetation of area 2 was modified by tree and shrubs cutting and therefore the value of IKS decreased. No changes were made in the following year and the area was overgrown, which also affected the increase in the IKS value for 2017. The same progress was also recorded in the area 5, where shrubs were removed and frequent mowing during 2016 and subsequent succession in 2017. Area 3 was grazed by cattle, which was more intense in 2017 reflected in IKS 0 . The waterside vegetation of area 4 was treated during all 3 years by removing shrubs and trees causing annual IKS values to fall.

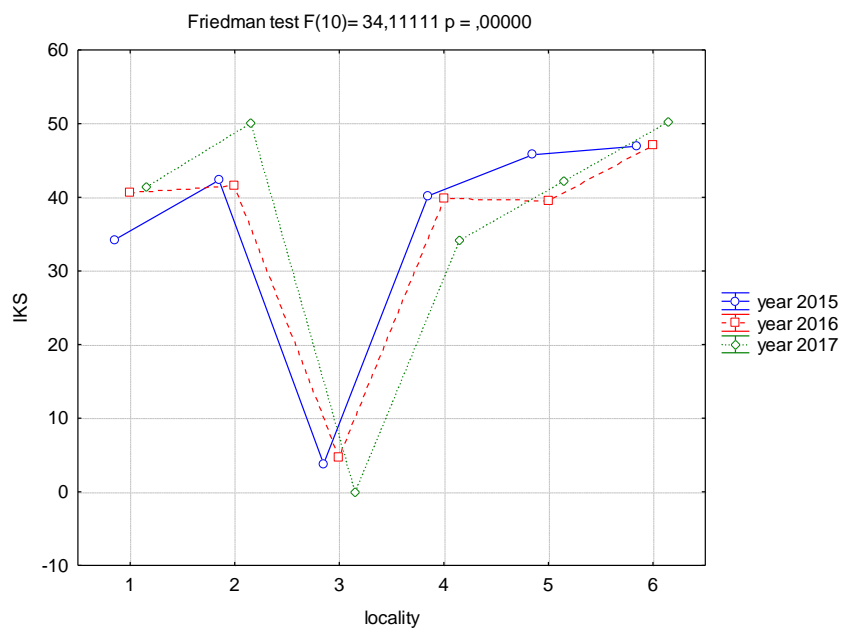

Figure 4. Analysis of IKS variation of individual ares by Friedman test (ANOVA) from 2015 to 2017 
Polynomial regression (quadratic distribution) for evaluation of IKS change in 2015-2017 was used. Using the regression model we expressed the relationship (correlation) between IKS at the areas to the harvest years. The value of the correlation coefficient for area 1 is $(\mathrm{r}=0.90)$, which indicates an almost perfect relationship. For areas $2(r=0.81), 3(r=0.75), 4(r=0.89)$ and $6(r=0.87)$ the relationship is very large. For area $5(\mathrm{r}=0.56)$ the relationship is large. The overall suitability of the regression model is statistically significant for all areas. The results are as follow: area 1 $(\mathrm{p}$-value $=0.02), 2(\mathrm{p}$-value $=0.03), 3(\mathrm{p}$-value $=0.04), 4(\mathrm{p}$-value $=0.02), 5$ $(\mathrm{p}$-value $=0.01)$ and $6(\mathrm{p}$-value $=0.03)$ thus confirms the effect of years on the IKS values of the study areas. Based on the regression equations shown in Fig. 5 we can predict the IKS value of individual areas for year 2020: for area 1 (IKS = 53), area 2 $(\mathrm{IKS}=59)$, area $3(\mathrm{IKS}=0)$, area $4(\mathrm{IKS}=26)$, area $5(\mathrm{IKS}=35)$ and area 6 $(\mathrm{IKS}=54)$. The predicted results may be fulfilled in areas 1,2 and 6 in the case of continued spontaneous succession in which the areas are overgrown by vegetation (areas not managed). For areas 3,4 and 5 the trend will be reversed and areas will be modified by anthropogenic activity. From the above results we can conclude, that the quality of habitats and class will change as follows. Areas 1,2 and 6 rise from Class III (affected) to Class IV (little affected). For area 3 the quality and habitat class will remain unchanged I (very strongly affected). In areas 4 and 5 there will be a decline from Class III (affected) to Class II (heavily affected).

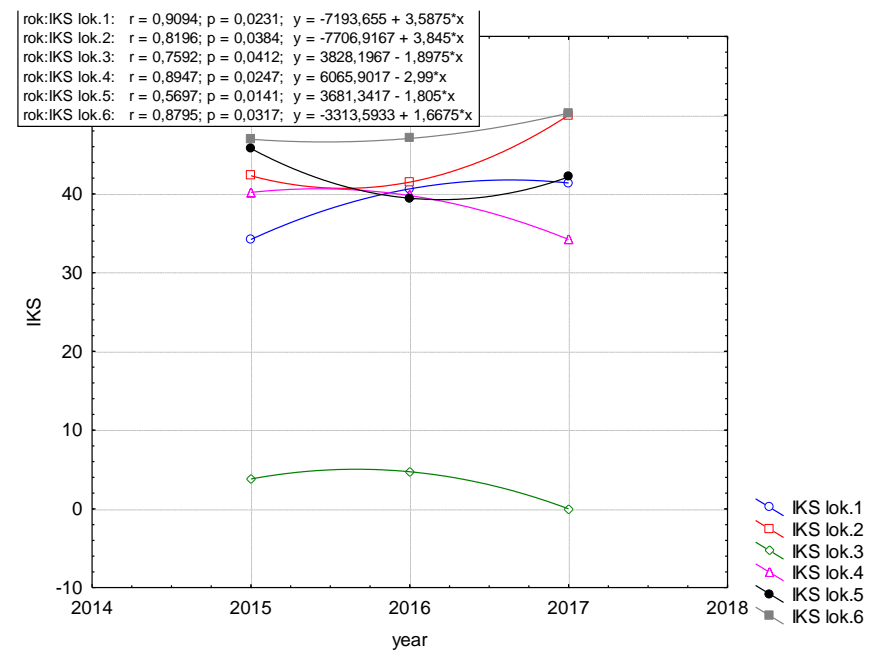

Figure 5. Polynomial regression of IKS values 2015 - 2019

Using the exponential distribution we predicted that IKS $=70$ would be 5 years later (with $99 \%$ probability) in areas 1,2 and 6 . In the same way we predicted IKS $=10$ by 5 years (with $57 \%$ probability) in areas 4 and 5.

The correlation of luminous intensity, moisture, $\mathrm{pH}$ was determined by redundancy analysis (RDA), which points out on values of explained variability of species data of the first ordination axis $43.7 \%$ and on the second ordination axis $64.5 \%$. The variability of the species set explained by the environmental variables captured by the first ordinate axis $57 \%$, the second axis captured by $84.2 \%$. Carabidae are ordained into 4 clusters (Fig. 6), the first cluster (I) consisted of species correlating with luminous intensity. The second cluster (II) was represented by $\mathrm{pH}$-binding species. The third (III) cluster was 
represented by species correlating with moisture. The last cluster (IV) consisted of species that were not ordained in any cluster and are not influenced by the investigated factors (luminous intensity, moisture and $\mathrm{pH}$ ). The Monte Carlo permutation test verified the $\mathrm{HO}$ hypothesis: environmental factors (luminous intensity, moisture and $\mathrm{pH}$ ) did not affect the species of the Carabidae family, if $\mathrm{p}>\mathrm{p} \alpha=>$ do not reject $\mathrm{H} 0$ at the stated level of statistical significance $\mathrm{p} \alpha=0.05$. As statistically significant factor ( $\mathrm{p}$-value $=0.002$ ) we confirmed luminous intensity, in others we did not confirm statistical significance: moisture $(\mathrm{p}$-value $=0.378)$ and $\mathrm{pH}(\mathrm{p}$-value $=0.268)$. Factors were not correlated with each other, maximum inflation factor $=4.247$.

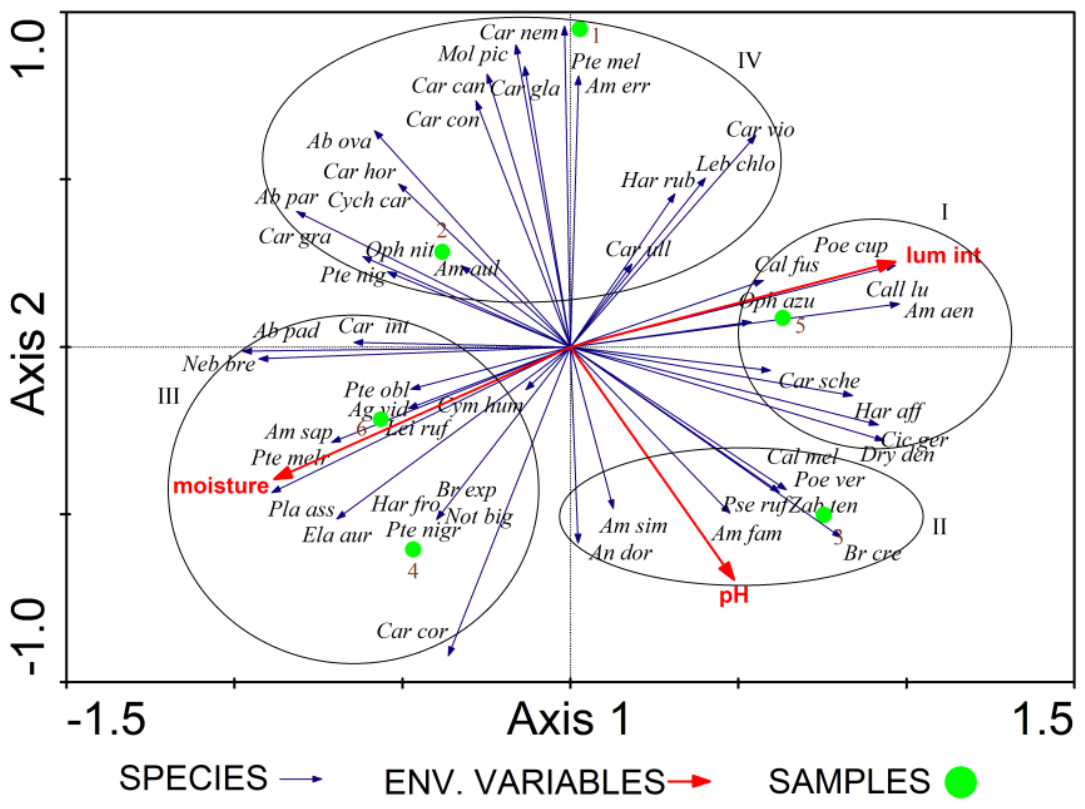

Figure 6. RDA analysis of ground beetles and environment variables (luminous intensity, moisture, pH). Explanatory notes: lum int - luminous intensity

\section{Discussion}

Our research evaluated the anthropogenic effect (agriculture, treatment of waterside vegetation, mowing meadows) on the Carabidae cenosis. The species were divided into bioindication groups according to Farkač et al. (2006) and the subsequently calculated Index of the Carabidae IKS according to Nenadál (1998).

The lowest IKS value was recorded in area 3 (IKS $=0$ ) with the prevalence of eurytopic species (IKS) over adaptable (IKS). This fact confirms a very strong disruption of the area (habitat quality class I). The same fact was pointed out by Langraf et al. (2016), Igondová and Majzlan (2015), Št’astná and Bezděk (2004), Purchart and Kula (2005), Baranová et al. (2013) and Lemic et al. (2017) whose in their work have noticed the prevalence of eurytopic species (IKS) over adaptable (IKS) in agricultural areas and Jad'ud'ová et al. (2016) in permanent grassland. Other areas had a habitat quality class III, indicating a moderate disturbance with adaptable species predominating over eurytopic species. The same fact was noted in their works Stluka (2013), and Rajová (2007).

A gradual increase in IKS over 3 years was observed in areas 1 and 6, which was influenced by succession. Area 1 (meadow) was not mowed and area 6 (nitrophilic 
waterside) had no treated waterside vegetation. Species from group $\mathrm{R}$ were also recorded in the areas. The decrease in IKS values over the study period was found in the areas 3 and 4 in which significant anthropic activity took place. A higher number of $\mathrm{E}$ group species was also recorded. Area 3 (pasture) was grazed by cattle and area 4 (nitrophilic waterside vegetation) had trimmed waterside vegetation by cutting trees and shrubs. Areas 2 (nitrophilic waterside vegetation) and 5 (fallow field) had a decrease in IKS values and an increase in group E species during 2016, in the following 2017 IKS values increased. With increasing anthropic intervention IKS values decreased and the number of eurytopic species that replaced adaptable increased. As a result of decreasing interventions IKS values increased and the number of group A and $\mathrm{R}$ species increased as well. The same was found by Langraf et al. (2019), Niemel et al. (2002), Elek et al. (2001), Finch (2005) and Wiezik et al. (2007).

Polynomial regression models assume the continuing trend of succession (area1, 2 and 6), where we predicted by exponential distribution $99 \%$ probability of IKS increase to 70 in 2022. For areas 3, 4 and 5 we predicted a higher impact of anthropogenic activity. Exponential distribution predicted $57 \%$ probability of reducing IKS to 10 for 2022.

Vician et al. $(2010,2011)$ cited as typical species mainly associated with arable land Clivina fossor, Calathus fuscipes, Amara aenea, Anchomenus dorsalis, Harpalus affinis, $H$. distinguendus and Pseudoophonus rufipes. The presence of these species with a higher number of individuals was recorded in areas 3 and 5 adjacent to the farmed land.

\section{Conclusion}

The different intensity of anthropogenic impacts (developed agriculture, treatment of waterside vegetation, mowing meadows) on Carabidae species in six study areas representing 4 habitat types was evaluated.

We confirmed statistically significant changes in values in years 2015-2017 for all study areas using the IKS index. We found a low IKS value $=0$ with a predominance of eurytopic species on habitat quality class $3=\mathrm{I}$, indicating a very strong disturbance. Other areas had habitat quality class III, indicating moderate disturbance with the prevalence of adaptable species. The above facts have confirmed our first working hypothesis.

Significant differences in the number of bioindicating species (groups A, E, R) were observed for eurytopic species in years 2016-2017, indicating a more intensive agricultural use of the landscape (cattle grazing, expansion of fields at area 5). Bioindication group R also increased in years 2016-2017, which was influenced by the spread of group R species to area 1. Species belonging to group A showed year-on-year changes, but not so significant. It follows from the above that the second and third working hypotheses are confirmed. The arable land species were represented by a higher number of individuals: Amara aenea, Anchomenus dorsalis, Calathus fuscipes, Harpalus affinis and Pseudoophonus rufipes on areas 3 and 5.

The regression models predicted the continuation of succession on areas 1,2 and 6, where we predict a $99 \%$ probability of IKS to rise to 70 in 2022 at exponential distribution. The above facts confirm the reduction of anthropic activity in these localities. We predicted a higher impact of anthropogenic activity and a decrease in IKS 
values by the regression polynomial model on areas 3, 4 and 5 . We also pointed on the $57 \%$ probability of reducing IKS with a value of 10 in 2022 by exponential distribution.

In order to maintain the original biodiversity of the carabidae family, it is possible to adjust the management and management of the investigated sites. Verification of the success of the introduced changes during the continuation of the results in the years referring to the forecast.

Acknowledgements. This research is supports by the project VEGA 1/0496/16: Assessment of natural capital, biodiversity and ecosystem services in Slovakia - basis for practical implementation of integrated environmental policy.

\section{REFERENCES}

[1] Baranová, B., Fazekašová, D., Jászay, T., Manko, P. (2013): Ground beetle (Coleoptera: Carabidae) community of arable land with different crops. - Folis faunistica Slovaca 18(1): 21-29.

[2] Barilla, J., Simr, P., Sýkorová, K. (2016): Microsoft excel 2016 podrobná užívatel'ská príručka. - In: Computer Press, Brno.

[3] Burgio, G., Campanelli, G., Leteo, F., Ramilli, F., Depalo, L., Fabbri, R., Sgolastra, F. (2015): Ecological Sustainability of an Organic Four-Year Vegetable Rotation System: Carabids and Other Soil Arthropods as Bioindicators. - Agroecology and Sustainable Food Systems 39(3): 295-316.

[4] Cardamo, H. A., Spence, J. R. (1994): Crop type effects on the activity and distibution of ground beetles (Coleoptera, Carabidae). - Environmental entomology 23(3): 123-140.

[5] Elek, Z., Magura, T., Tóthmérész, B. (2001): Impacts of non-native Norway spruce plantation on abundance and species richness of ground beetles (Coleoptera: Carabidae).

- Web Ecology 2: 32-37.

[6] Farkač, J., Kopecký, T., Veselý, P. (2006): Využitie střevlíkovitých (Coleoptera, Carabidae) fauny Slovenska k indikaci kvality prostředí. - Ochrana Př́rody 25: 226-242.

[7] Finch, O. D. (2005): Evaluation of mature conifer plantations as secondary habitat for epigeic forest arthropods (Coleoptera: Carabidae; Aranae). - For. Ecol. Manag. 204: 2336.

[8] Heydeman, B. (1955): Carabiden de Kulturfelder ökologische Indikatoren. Wanderversammlung Deut. Ent. Ber. 7: 172-185.

[9] Hůrka, K. (1996): Carabidae České a Slovenské republiky. - Zlin, Czech Republic: Kabourek.

[10] Igondová, E., Majzlan, O. (2015): Assemblages of ground beetles (Carabidae, Coleoptera) in peatland habitat, surrounding dry pine forests and meadows. - Folia Oecologica 42(1): 21-28.

[11] Jad’ud'ová, J., Kanianska, R., Kizeková, M., Makovníková, J. (2016): Evaluation of Habitat Provision On the Basis of Carabidae Diversity in Slovak Permanent Grasslands. World Multidisciplinary Earth Sciences Symposium (WMESS 2016), Earth and Environmental Science 44: 1-5.

[12] Langraf, V., Petrovičová, K., David, S., Schlarmannová, J. (2016a): The bioindication importance of the Carabidae communities of Veporské vrchy and Juhoslovanská kotlina. - Ekológia (Bratislava) 35(2): 126-135.

[13] Langraf, V., Petrovičová, K., David, S., Schlarmannová, J. (2016b): Bystruškovité (Carabidae) Veporských vrchov a Juhoslovenskej kotliny. - Ochrana prírody 28: 29-38.

[14] Langraf, V., Petrovičová, K., David, S., Ábelová, M., Schlarmannová, J. (2017): Body volume in ground beetles (Carabidae) reflects biotope disturbance. - Folia Oecologica 44(2): 114-120. 
[15] Langraf, V., David, S., Schlarmannová, J. (2018a): Ekologicka charakteristika bystruškovitych (Coleoptera: Carabidae) Stolickych vrchov a lučenskej Kotliny. Ochrana prírody 31: 13-19.

[16] Langraf, V., Petrovičová, K., David, S., Kanská, M., Nozdrovická, J., Schlarmannová, J. (2018b): Change Phenotypic Traits in Ground Beetles (Carabidae) Reflects Biotope Disturbance in Central Europe. - Journal of the Entomological Research Society 20(2): 119-129.

[17] Langraf, V., Petrovičová, K., David, S., Nozdrovická, J., Petrovič, F., Schlarmannová, J. (2019): The Bioindication Evaluation of Ground Beetles (Coleoptera: Carabidae) in Three Forest Biotops in the Southern Part of Central Slovakia. - Ekológia (Bratislava) 38(1): 25-36.

[18] Lemic, D., Čačija, M., Viric, G. H., Drmic, Z., Bažok, R., Pajac, Ž. I. (2017): The Ground Beetle (Coleoptera: Carabidae) Community in an Intensively Managed Agricultural Landscape. - Applied Ecology and Environmental Research 15(4): 661-674.

[19] Nenadál, S. (1998): Využití indexu komunity střevlíkovitých (Coleoptera,Carabidae) pro posouzení antropogenních vlivů na kvalitu prŕrodního prostředí. - Vlastivědný Sborník Vysočiny 13: 293-312.

[20] Niemelä, J., Kotz, J. D., Venn, S., Penev, L., Stoyanov, I., Spence, J., Hartley, D., Oca, M. E. (2002): Carabid beetle assemblages (Coleoptera, Carabidae) across urban-rural gradients: an international comparison. - Landscape Ecology 17: 387-401.

[21] Nietupski, M., Kosewska, A., Markuszewski, B., Sadej, W. (2015): Soil management system in hazelnut groves (Corylus sp.) versus the presence of ground beetles (Coleoptera: Carabidae). - Journal of Plant Protection Research 55(1): 26-34.

[22] Novák, K. (1969): Metody sběru a preparace hmyzu. - Academia, Praha, 243 p.

[23] Porhajašová, J., Petřvalský, V., Macák, M., Urminská, J., Ondrišík, P. (2008): Occurrence of species family Carabidae (Coleoptera) indepence on the input of organic matter into soil. - Journal Central European Agriculture 9(3): 557-565.

[24] Porhajašová, J. (2009): The evaluation of bioindicators abilitiens of selected zoocoenosis (Carabidae, Coleoptera) in dependence on different farming systems. - Environmental protection and food safety in crop production 262-266.

[25] Purchat, L., Kula, E. (2005): Ground beetles (Coleoptera, Carabidae) agrocenoses of spring and winter wheat. - Acta univ. agric. et silvic. Mendel. Brun., 2005, LIII, No. 5: 125-132.

[26] Rajová, Š. (2007): Využití hmyzu k výuce biologie. Střevlíkovití (Coleoptera: Carabidae) Klánovického lesa a posouzení stavu jeho zachovalosti metodou bioindikace. - $\mathrm{PhD}$ thesis, Katedra biologie a ekologické výchovy Pedagogické fakulty Univerzity Karlovy.

[27] Ružičková, H., Halada, L., Jedlička, L., Kalivodová, E. (1996): Biotopy Slovenska. Bratislava, Ústav krajinnej ekológie Slovenskej Akadémie Vied.

[28] Statsoft, inc. (2004): Statistica Cz [Softwarový systém na anylýzu dat], verze 7. Www.StatSoft.Cz.

[29] Stluka, P. (2013): Vliv managementu na biodiverzitu lesních ekosystémů- epigeičtí brouci na vybraných biotopech Písecka. - Diploma thesis, Zemědělská fakulta, Jihočeská Univerzita v Českých Budějovicích.

[30] Št’astná, P., Bezděk, J. (2004): Carabidae a ostatní čeledi brouků (Coleoptera) zjištění v zemních pastech v polní agrocenóze v Sivicích. - Zoologické dny Brno 2004: 104-105.

[31] Ter Brak, C. J. F., Šmilauer, P. (2002): CANOCO Reference Manual and User's Guide to Canoco for Windows. - Centre for Biometry, Wageningen. Ithaca NY, USA.

[32] Vician, V., Stašiov, S., Kočík, K., Hazuchová, L. (2010): Carabidae (Coleoptera) Structure on Variously Managed Agricultural Land of Podpol'anie area. - Acta facultatis ecologiae, Zvolen 22: 133-146.

[33] Vician, V., Stašiov, S., Kočík, K., Hazuchová, L. (2011): Structure of the Carabids (Coleoptera: Carabidae) Associations on Variously Managed Agricultural Land of Podpol'anie area and their bioindication. - Acta facultatis ecologiae: 123-131. 
[34] Wiezik, M., Svitok, M., Dovčiak, M. (2007): Conifer introductions decrease richness and alter composition of litter-dewlling beetles (Coleoptera) in Carpathian oak forests. - For. Ecol. Manag. 247: 61-71. 